\title{
SCOTTISH NEWSPAPERS \\ AND THE CRISIS OF THE PRINT PRESS: \\ JOURNALISTIC AUTONOMY AND DIGITAL TRANSITION \\ IN A LIBERAL MEDIA SYSTEM
}

\author{
Marina Dekavalla ${ }^{1}$
}

\begin{abstract}
This article examines how members of the Scottish newspaper industry view the current crisis of the print press and the future of their titles. It looks at how newspaper companies are attempting to address the challenges posed by digital transition and competition in a small market, and where they believe the solution to this problem lies. The analysis is based on input from interviews with editors and managers as well as circulation data from the last fifteen years. Findings suggest that, in line with the characteristics of a liberal media system, newspaper organisations believe that it is up to the industry, rather than the state, to resolve this systemic issue and to ensure the survival of their products.
\end{abstract}

The print press in most Western countries has faced a dramatic decline over the last twenty years, precipitated by a major change in how the public accesses news, which was introduced by digital platforms. Newspapers in large and small markets alike are losing readers and advertising revenue, which has put into question their future sustainability. For those operating in smaller markets the challenge is arguably greater due to the relatively small potential readership. This is especially the case when they operate near a

1 Marina Dekavalla is a senior lecturer in journalism at the University of Sussex, UK. Her research interests include political journalism and the public sphere, and the future of the news industries in the digital era.

Recherches en communication, $\mathrm{n}^{\circ} 44$ - Article published on 10/04/2018 
larger market with bigger players publishing in the same language and competing with the indigenous press.

This article explores how this crisis has affected Scottish newspapers and how members of the indigenous press industry view different potential solutions to the problem, originating in state or private initiative. It is based on interviews conducted between 2010 and 2016, as well as circulation data from the last fifteen years. More specifically, interviewees include editors in chief and managing directors, working at the time of the interviews for Scottish indigenous daily morning titles (the Scotsman, the Herald, the Daily Record, the Courier, and the Press and Journal), as well as the Scottish Newspapers Society, the body that acts for the interests of the industry. The paper focuses particularly on morning titles produced exclusively for a Scottish audience, and therefore the sample excludes London-based newspapers, which are also sold in Scotland, as well as evening or weekly local titles targeting individual cities or towns ${ }^{2}$.

Scotland is one of the nations that make up the United Kingdom. It has had a devolved parliament since 1999 and a distinctive public sphere, which has been sustained over the three centuries of its union with England. Scotland's indigenous press has traditionally played a significant part in maintaining this separate space for national debate. Scotland has been negotiating its identity and place in the UK with an independence referendum in 2014 and - at the time of writing -ongoing debate about the possibility of a second referendum in the future. In this context, the availability of platforms for news, democratic deliberation and expression of opinion takes on an even more significant role.

In what follows, I shall first discuss the challenges the print press has been dealing with in many Western countries, before exploring how these have affected Scottish newspapers in particular. I will then examine how interviewees from the Scottish

2 Although the Courier and the Press and Journal target regions in the North of Scotland, they were included in the sample because, by contrast to most local titles, they are daily morning papers and their circulations are comparable to those of the Scotsman and the Herald. 
press view two potential solutions to the problem: state support and solutions originating in the industry itself.

\section{Solving a business model crisis}

A business model is the way in which an organisation delivers its products or services, generates value and makes a profit from this activity (Fetscherin \& Knolmayer, 2004). It is a fundamental logic, which explains how a business creates profit, guides how its operations are managed, and supports its future strategic development (Spieth et al., 2014). Traditionally the dominant business model for newspapers consisted in providing content to paying readers and at the same time selling access to these readers to advertisers.

This model sustained the provision of news for several decades because the legacy press was a significant platform for the public to access news as well as for advertisers to reach their targeted demographics. All this changed gradually with the introduction of competition from an increasing number of platforms. In the UK, newspapers reached a peak in their sales in the 1950s, and thereafter have been losing readers, as a result of competition initially with television, and then, at a much more accelerated pace, with online media (Dekavalla, 2015). The decline of the press is a pattern that affects most Western markets and is not unique to Scotland or Europe. To survive the loss of readers and advertising income, traditional media organisations around the world have had to expand online, revise their previous business model and seek "a balance between old and new revenue logics", a process with which different companies have engaged to different degrees (Leminen et al., 2016, p. 195).

The traditional business model, which made the print news industry viable and profitable for many decades, is thus no longer sustainable in either large or small markets. Two routes for resolving this problem dominate public debate, depending on one's position in relation to market liberal ideals. One is to let the industry find its own way through the crisis, which may involve experiments with different forms of content and monetisation, as 
well as the loss of some of the less successful newspaper titles, but might eventually allow some of the old organisations to survive or new players to emerge. The concern usually expressed about this solution is the possibility of losing not just a few companies, but a public good, which contributes to informed citizenry, democratic participation, accountability, and diversity of perspectives (Pickard, 2011). According to this argument, if the market is left to find its own solutions, there is no guarantee that future media business models will remain able to fund news making and this may create a democratic deficit.

The second route involves sources of funding for the press from outside the corporate domain. Some of the proposed solutions here include the establishment of non-profit organisations supported financially by institutions, donations or crowdfunding (Pickard, 2011; Cagé, 2016); or state funding for the press. State funding may take the form of direct aid, namely financial assistance to publishers, or indirect aid, which could be VAT reductions or exemption, tax breaks or other forms of less direct support, such as public sector advertising (Murschetz, 2014). As Picard (2014) points out, news has always depended on sources other than its consumers for funding, whether these were states, political parties or advertisers. Although newspapers in Western markets have generally been the object of less intervention compared to other industries, Western democracies have and still do intervene in press economics to different degrees, some with direct subsidies (general or selective) and some with indirect support, depending on their broader economic philosophies (Picard, 1985).

These economic philosophies vary in different media systems (Hallin \& Mancini, 2004), and are important in determining not only the extent to which states support the press, but also whether and in what form newspaper organisations see state support as acceptable. A common objection to state aid, for example, is that it may compromise press freedom and scrutiny of those in power (Nielsen \& Linnebank, 2011). Although, as will be seen later in this article, this view is also dominant in the Scottish news industry (particularly among editors) not all forms of state 
support are seen in this way, even within a media system that is generally oriented towards market liberalism.

Until now though, the press industry itself has been the actor most directly dealing with the crisis, even in countries where newspapers enjoy some level of support from the state. The press industry internationally has been seeking a new business model that will allow established brands to survive and monetise online content. They have been experimenting with different forms of digital provision (paywalls, apps for mobile devices, online subscriptions, digital kiosks), the degree of overlap between their digital and physical products, and the pricing of their offering on different platforms (Fetscherin \& Knolmayer, 2004). Often these experiments have been accompanied by cost-cutting in print newsrooms, lay-offs and increased workloads for staff (Tang et al., 2011). Still most newspapers, even those that enjoy large readership figures online, are struggling to monetise this audience to the extent that its size would justify (Franklin, 2012). For many of these titles, their print product remains the main source of revenue, despite their online success (Krumsvik, 2012). This is because, although online advertising has been the fastest growing sector throughout the last decade, most of this spend has been going to search engines and social media advertising. For example, in $201648 \%$ of the UK's total digital adspend went to search, while $46 \%$ of online display advertising was spent on social media sites (IAB, 2017).

\section{Scotland: market solutions to a market problem?}

Scotland, as a constituent nation of the UK, is classified as a liberal media system (Hallin \& Mancini, 2004), where the press (although editorially highly partisan) is primarily ruled by market conditions. In this section, I will argue that this is consistent with a dominant logic among newspapers in Scotland, which sees the industry as responsible for solving its own problems and any direct financial support from outside the industry as potentially threatening the editorial independence of the press. First, I will discuss the situation faced by Scottish papers and then examine 
the industry's attitudes toward the two kinds of solutions discussed in the previous section: state intervention and business model innovation. I will propose that interviewees' preferred solutions to the problem position the industry itself as the actor responsible for the survival of the press and this is consistent among both editors and managers.

\section{The decline of the Scottish press}

The Scottish newspaper market is highly competitive, as it is a small market within a bigger UK-wide one. Fifteen daily morning titles and an equivalent number of Sunday papers, alongside a large number of local publications, all compete for a readership of just above five million. Daily and Sunday papers can be categorised in two groups: the indigenous Scottish press, comprising titles like the Scotsman, the Herald and the Daily Record, which are written for a Scottish readership and sell most of their copies in Scotland; and the London-based newspapers sold throughout the country, some (but not all) of which print dedicated Scottish editions, such as the Scottish Sun and the Scottish Daily Mail. These Scottish editions share most of their content with their London editions and have some pages produced for the Scottish version. They represent a major source of competition for the indigenous titles, which culminated when in 2006 the Scottish Sun took from the Daily Record the position of the best-selling newspaper in Scotland, a position it holds to this day.

Tables 1 and 2 show that both categories of newspapers have lost a very large part of their circulations over the last fifteen years. As explained previously, this is part of an international trend, though in Scotland the competition has been fiercer due to the large number of players in the market for the size of the population (McNair et al., 2010, Dekavalla, 2015). 
Table 1. Scottish circulations of daily press

\begin{tabular}{|c|c|c|c|}
\hline \multirow{2}{*}{\multicolumn{4}{|c|}{ Indigenous Scottish titles }} \\
\hline & & & \\
\hline The Scotsman & 72,231 & 65,773 & 22,740 \\
\hline The Herald & & 76,404 & 32,141 \\
\hline The Daily Record & 493,352 & 426,429 & 171,196 \\
\hline Aberdeen Press and Journal & 92,406 & 83,947 & 56,422 \\
\hline Dundee Courier & 85,234 & 77,428 & 43,031 \\
\hline \multicolumn{4}{|l|}{ London-based titles } \\
\hline The Daily Telegraph & 23,866 & 23,692 & 15,267 \\
\hline The Times & 31,079 & 29,916 & 22,051 \\
\hline The Guardian & 16,337 & 16,682 & 8,487 \\
\hline Scottish Sun & 380,042 & 368,818 & 218,069 \\
\hline Scottish Daily Mail & 130,187 & 130,179 & 86,503 \\
\hline Scottish Daily Express & 84,403 & 86,775 & 43,478 \\
\hline Scottish Daily Mirror & 83,453 & 47,014 & 13,096 \\
\hline The Daily Star - Scotland & 58,167 & 96,619 & 42,139 \\
\hline
\end{tabular}

Data source: www.abc.org.uk

Table 2. Scottish circulations of Sunday press

\begin{tabular}{|c|c|c|c|}
\hline & Jan.2003 & Jan.2006 & Jan.2016 \\
\hline \multicolumn{4}{|l|}{ Indigenous Scottish titles } \\
\hline Scotland on Sunday & 77,059 & 77,890 & 22,060 \\
\hline Sunday Herald & & 63,174 & 25,006 \\
\hline Sunday Mail & 589,528 & 516,033 & 188,178 \\
\hline Sunday Post & & 293,700 & 121,929 \\
\hline \multicolumn{4}{|l|}{ London-based titles } \\
\hline Sunday Telegraph & 26,375 & 21,792 & 13,059 \\
\hline Sunday Times & 81,447 & 77,468 & 44,963 \\
\hline The Observer & 23,659 & 25,422 & 12,106 \\
\hline $\begin{array}{l}\text { Scottish Sun - Sunday } \\
\text { (ex NoW) }\end{array}$ & 362,091 & 341,178 & 160,642 \\
\hline Scottish Mail on Sunday & 113,197 & 131,529 & 74,072 \\
\hline Scottish Sunday Express & 57,253 & 62,897 & 24,923 \\
\hline Scottish Sunday Mirror & 53,413 & 43,413 & 11,753 \\
\hline $\begin{array}{l}\text { Daily Star on Sunday - } \\
\text { Scotland }\end{array}$ & 35,275 & 34,468 & 24,465 \\
\hline
\end{tabular}

Data source: www.abc.org.uk 
The indigenous Scottish press was established in the $17^{\text {th }}$ and $18^{\text {th }}$ centuries and the titles mentioned above changed ownership several times in their history (Hutchison, 2008). Most indigenous newspapers are currently owned either by companies outside Scotland (for instance the Herald is owned by Newsquest, a subsidiary of the US Gannett group), or by companies whose financial interests are UK-wide (for instance Johnston press, the owners of the Scotsman, also own a large number of local newspapers in England and in Scotland). The Herald and the Scotsman market themselves as Scottish national newspapers, even though the majority of their readership is located in their respective cities - in Edinburgh for the Scotsman and Glasgow for the Herald. A geographically diverse readership is of course not a requirement for a newspaper to be considered national, with many London-based UK nationals also having the majority of their readers in the South East of England (MacInnes et al., 2007). Still, the impact of ownership patterns on indigenous Scottish titles is a much-debated issue, especially as large corporate groups have been known for expansionist business strategies, and tactics aiming to "maximise income" and "minimise cost", often by cutting staff (Baines, 2014, p. 21).

Two regional newspapers in the North of Scotland, the Press and Journal and the Courier, which are not marketed as nationals, have been doing relatively better than the central Scotland nationals. Although they too have lost a significant part of their readership (Table 1), the decline has been comparatively smaller. This is attributed by members of the industry to more modest online expansion (although they have some online provision, this includes a small part of their print content) but also more modest business expansion (McNair et al., 2010). At the same time though, these titles focus on a geographical niche and provide relatively unique content for these areas - a feature that has generally been connected to successful press brands (McDowell, 2011). That said, even these titles have lost about half their readership in the last fifteen years. 


\section{The Scottish press and the state}

There are no direct state subsidies for the press in Scotland. Media policy is reserved to the UK parliament, and the UK state generally does not interfere directly in the press, apart from regulating ownership (Picard, 1985). There are no subsidies specific to the presses that operate in smaller markets in the UK's nations either. An exception is Welsh language papers, which are supported by the Arts Council and the Welsh Assembly (Baines, 2014). The major Scottish newspapers examined here though are all published in English and therefore there are no similar concerns about maintaining a linguistic community. Gaelic language programming is supported in broadcasting (e.g. Gaelic channel BBC Alba is co-funded by BBC Scotland and the Scottish Government), but there is no equivalent in print media at the time of writing ${ }^{3}$.

The UK (and therefore also the Scottish) press industry has traditionally enjoyed some forms of indirect state support. Print newspapers in the UK are exempt from VAT on copy sales and advertising, a form of support which Nielsen and Linnebank (2011) estimate corresponded to $£ 594$ million in 2008 for the whole of the UK. Indeed this policy is not unique to the UK, as some form of tax relief is one of the two most common types of state support provided to the media across a range of nations with different media policies (Nielsen \& Linnebank, 2011).

However, VAT exemption is often overlooked as a form of aid when members of the Scottish press industry discuss the current crisis for a number of reasons. First, it is a general form of support, equally available to all companies in the market, including the bigger UK-wide competitors of the indigenous Scottish press. Therefore, it does not favour specifically the press in small nations like Scotland. Second, it is historically established for several decades and newspapers were operating with it long before the digital transition posed new challenges

3 Until 2009, Bòrd na Gàidhlig, the Scottish Government's public body responsible for Gaelic, funded An Gàidheal Ùr, a Gaelic supplement in the West Highland Free Press, which has since been discontinued. 
to their finances; it thus makes little difference in the context of their current problems. Third, it is a tax relief based on sales and advertising, both of which are currently fast declining.

The UK government recently introduced another form of tax relief for the local press in England, which was explicitly framed as a response to the challenges faced by local publications in their transition to digital platforms. The scheme, introduced in April 2017, offers a $£ 1,500$ business rate discount for office space occupied by local newspapers for up to two years. This scheme is not available in Scotland at the time of writing, and has not been expanded to national publications.

Online competition by the $\mathrm{BBC}$, the publicly funded broadcaster, is a long-term concern of both the Scottish and UKwide commercial press. The press's argument is that the $\mathrm{BBC}$ uses television license fee funds to provide high quality digital news platforms free of charge, and introduces unfair competition against their own attempts to monetise their online provision (McNair et al., 2010). In an attempt to increase collaboration between the $\mathrm{BBC}$ and regional and local news organisations, the new BBC charter in 2017 introduced an $£ 8 \mathrm{~m}$ scheme supported by the license fee, which has allocated funds to 58 news organisations throughout the UK, in order to employ Local Democracy Reporters to cover local councils and public institutions. Their output will be shared with more than 700 media organisations, which have signed up to the Local News Partnership Scheme (BBC, 2017). Ten of these contracts have been allocated to press companies in Scotland. The scheme also allows these companies access to use regional and local $\mathrm{BBC}$ video and audio content on their websites, as well as secondments to build data journalism expertise in their staff.

Public sector advertising is another form of indirect support traditionally enjoyed by the press (Baines, 2014). In the past, this was a significant source of income for Scottish titles, both national and local. According to one of the Scottish national newspaper editors I interviewed, until about 2009 all public sector recruitment advertisements and public information notices would appear in the print press because this was "the way you 
communicated with markets, [...] it was the best way to tell people things". However, public authorities gradually launched their own online portals, which gave them the opportunity to communicate directly with the public in a more cost-effective way, and most advertising migrated there. According to interviewees from the Scottish press, there is still "a reasonable amount" of public sector advertising in print, but the great majority of the advertising they used to receive is no longer there. Authorities rationalised their spending especially in recruitment adverts, which are now placed on dedicated public sector recruitment websites.

Both editors and managers interviewed were highly sceptical about direct state subsidies, arguing that accepting financial aid would compromise their freedom and ability to scrutinise public authorities. For instance:

I think the freedoms and the distancing between us and the political machine are things which we value quite highly $[\ldots]$ that we are not reliant on political patronage to continue to exist. I think tradition is not strong enough. I think it's a principle.

Director, Scottish Newspaper Society

In line with the market liberal values, which permeate the UK newspaper industry, and are also expressed in the quote above, Scottish newspapers generally do not see direct state subsidy as a desirable solution. This position was consistent among both the editors and managers interviewed: although the director of the Newspaper Society quoted above had been a newspaper editor, and might thus be expected to be more concerned about ideals of journalistic independence, none of the managers interviewed were in favour of direct press subsidies from the state.

That said, indirect subsidies, such as maintaining public sector advertising in the press and VAT exemption, enjoy considerably more support. This is because these are not regarded as subsidy. Especially public sector advertising is seen as a service from which the authorities also benefit. According to the same interviewee: 
I think we'd like to see us higher up their creative discussions, when their marketing and communications strategies are being discussed, that we are a serious part of that.

Director, Scottish Newspaper Society

It seems therefore that market liberal ideals permeate the way the Scottish industry sees its relationship with the state. By contrast to direct financial support, public sector advertising is desirable because it is not seen as subsidy but as a fair exchange of funds for visibility.

\section{The industry's future in the industry's hands?}

For most of my interviewees in Scottish newspapers, the solution to the industry's problems lie primarily within the industry itself. Three solutions were proposed to the current crisis faced by the press, all of them deriving from the market: a) some editors suggested that the organisations that own the press need to have more modest business strategies, and focus on maintaining and improving their titles rather than seek to maintain profit levels of the past; b) both editors and managers proposed that investment in enriching and differentiating journalistic content will draw in readers; and c) most interviewees emphasised that the industry is still seeking an efficient strategy for incorporating digital platforms into their offering and finding the right business model will guarantee its survival. All three solutions are consistent with a liberal view of the media market that places responsibility on the industry rather than on the state. I will discuss each of the three proposed solutions below.

According to some of the newspaper editors interviewed, the business strategies of the big press corporations that own Scottish titles have exacerbated the problems the industry faced over the last decade. This argument is in line with the "self-inflicted wounds" narrative frame, which attributes the newspaper crisis to business decisions, debt load and disinvestment in content, rather than on broader systemic factors beyond the industry itself 
(Pickard, 2011). For example, the newspaper editor quoted below suggested that, at a time of new and increased competition from digital platforms, investment in journalistic content should have taken priority and attempting to maintain or increase the profits their investors enjoyed in the past is no longer feasible or helpful. In his view, business expansion together with cost-cutting and redundancies over the last decade weakened the position of these organisations and their newspapers. The solution therefore would lie in abandoning the profit-driven mindset of the past and turn their efforts towards improving journalistic content:

Those that don't invest in the quality of what they produce may find it difficult to survive. If papers are prepared to accept that the profit levels of 5-10 years ago are not sustainable, that there are still good returns to be made from newspapers, then I think the future's bright.

Editor, daily morning newspaper

The tendency to blame newspaper businesses for the troubles of the industry was understandably not shared by business managers. However, like editors, managers also suggested that quality and distinctiveness of content have played a role in the decline of newspaper readerships. According to a senior manager:

Sometimes newspapers are too similar to each other - they need to carry more unique, more distinctive content and that will attract more people to buy them.

Managing Director, daily morning newspaper

There is indeed some evidence, outside the Scottish case, that an increase in newsroom investment can lead to increase in both print subscriptions and the online performance of newspapers (Tang et al., 2011), because readers tend to prefer the same brands online that they trust offline and brand equity transfers across platforms (Kolo \& Vogt, 2004). According to Tang et al. (2011), this in turn translates into an increase in online and print advertising revenue. The proposal that ultimately newspapers need to manage and differentiate their brand, like all other 
types of consumer products, in order to maintain reader loyalty (McDowell, 2011) is consistent with a market liberal view of the media as commodities whose survival should be left to the rules of the market.

Alongside investment in content, brand differentiation and market positioning, interviewees also suggested that the solution lies in strategically planning how to incorporate innovation into newspapers' provision. One newspaper editor was openly critical of past business strategies in how digital innovation was managed:

As far as digital is concerned, the industry's problem has been not understanding what's the way forward. Not lacking the money to invest in it, but knowing what we're doing with it. Companies have spent the last decade thinking that audiences will come, if we build it then they will come, and the advertisers will surely follow because they can't ignore these audiences. Well, that hasn't happened.

Editor, daily morning newspaper

The excerpt reveals a perception that companies' efforts to develop their online provision did not deliver the results expected, and this is claimed to be the result of lack of clear strategy. Although this pessimism about past decisions was not shared by all editors, nor by the managers interviewed, most interviewees acknowledged that finding an efficient way to attract and monetise digital audiences has been an ongoing process over the last decade, which has involved some experimentation. For one of the managers interviewed, the industry is evolving alongside its audiences and its business model will eventually adapt to new demands:

As technology changes and improves, news and information has to follow suit. If people find it more convenient to get that news and information on a tablet or on a mobile, then we should provide it. But it needs to be within a viable business model, which is why I think you will increasingly have subscription-based content.

Managing Director, daily morning newspaper 
Even though they express different perspectives on how successful the industry has been so far in strategically managing digital innovation, both the last two quotes share the presumption that it is the industry's role to find a way to make the new digital business environment sustainable. None of the editorial or managerial staff interviewed proposed direct state support as part of the solution to the current crisis.

\section{Conclusion}

The double nature of the press as a commercial commodity and a democratic good underlies much of the debate around its survival. The business model that has allowed press companies to produce news by selling access to large audiences to advertisers is under severe challenge, but the service they provide is important beyond the market itself. The news media allow the public to learn about and participate in politics and public life, they hold the powerful to account and they enable a democratic public sphere to form and function. This role is particularly important in small markets. Although newspapers are not the only means through which national distinctiveness is formed and maintained, they have traditionally played a significant role in this process (Anderson, 1983). If traditional news organisations are lost, it is not clear what will take over this function and how it will remain financially viable.

The issues threatening the press in larger markets also affect the Scottish industry. What is particular about the Scottish case is the high degree of competition faced by newspapers, due to the large range of players in this small market, and the attitude of the industry against direct state subsidy and in favour of solutions instigated by the industry itself. In contrast to some of the other small markets in Northern Europe, the state does not directly subsidise the press and the industry does not seem to want it to. The conviction that newspapers are responsible to find a way to survive by adapting to the new market conditions is ingrained in this market-driven, liberal media system. The Scottish press 
receives indirect state support, but this is equally available to all UK newspapers and is not tailored to aid the specific market.

The Scottish press industry is optimistic about its own future and the organisations interviewed believe that their products will survive the crisis and find new ways to reach audiences. They see themselves as important platforms for national debate, especially as the issue of the future of Scotland in the UK remains open. Indeed the 2014 referendum saw a brief rise in their sales, despite their almost unanimous stance against independence, and it was directly followed by a new title launch: Newsquest (owners of the Herald) launched the National after the referendum, with an openly pro-independence agenda. The launch of new titles, even in this difficult financial environment, and the fight to maintain existing ones shows that the industry is still exploring different ways of making their brands attractive to an increasingly multiplatform readership.

\section{References}

Anderson, B. (1983). Imagined Communities. London: Verso.

Baines, D. (2014). United Kingdom: Subsidies and democratic deficits in local news. In P. Murschetz (ed.) State Aid for Newspapers, Media Business and Innovation. Berlin: Springer, pp. 337-355.

BBC (2017, 7 December). BBC announces media organisations which will employ Local Democracy Reporters as latest step in the Local News Partnerships. Available at http://www.bbc.co.uk/mediacentre/latestnews/2017/local-democracy-reporters (accessed 20 December 2017).

Cagé, J. (2016). Saving the media: Capitalism, Crowdfunding, and Democracy. Harvard University Press.

Dekavalla, M. (2015). The Scottish newspaper industry in the digital era. Media, Culture \& Society, 37(1), 107-114.

Fetscherin, M. \& Knolmayer, G. (2004). Business models for content delivery: An empirical analysis of the newspaper and magazine industry. International Journal of Media Management, 6(1\&2), 4-11.

Franklin, B. (2012). The future of journalism: Developments and debates. Journalism Practice, 6(5-6), 595-613.

Hutchison, D. (2008). The history of the press. In N. Blain \& D. Hutchison (eds.) The Media in Scotland (pp. 55-70). Edinburgh: Edinburgh University Press.

IAB (Internet Advertising Bureau UK) (2017). Full year 2016: Digital adspend results. Available at: https://iabuk.net/research/library/full-year-2016-digital-adspendresults 
Kolo, C. \& Vogt, P. (2004). Traditional media and their Internet spin-offs: An exploratory study on key levers for online success and the impact of offline reach. International Journal on Media Management, 6(1\&2), 23-35.

Krumsvik, A. (2012). Why old media will be funding journalism in the future. Journalism Studies, 13(5-6), 729-741.

Leminen, S., Huhtala, J., Rajahonka, M. \& Westerlund, M. (2016). Business model convergence and divergence in publishing industries. In A. Lugmayr \& C. Dal Zotto (eds.) Media Convergence Handbook, Vol 1. Media Business and Innovation (pp. 187-200). Berlin: Springer.

McDowell, W. (2011). The brand management crisis facing the business of journalism. International Journal on Media Management, 13(1), 37-51.

MacInnes, J., Rosie, M., Petersoo, P., Condor, S. \& Kennedy, J. (2007). Where is the British national press? British Journal of Sociology, 58(2), 185-206.

McNair, B., Dekavalla, M., Boyle, R. \& Meikle, G. (2010). Mapping Futures for News: Trends, Opportunities and Challenges for Scotland. Scottish Universities Insight Institute. Available at: http://www.scottishinsight.ac.uk/portals/50/futures_news_ report.pdf

Murschetz, P. (2014). State aid for newspapers: first theoretical disputes. In P. Murschetz (ed.) State Aid for Newspapers (pp. 21-46). Berlin: Springer.

Nielsen, R. \& Linnebank G. (2011). Public support for the media: A six-country overview of direct and indirect subsidies. Oxford: Reuters Institute for the Study of Journalism.

Picard, R. (1985). Patterns of state intervention in Western press economics. Journalism Quarterly, 62(1), 3-30

Picard, R. (2014). State support for news: Why subsidies? Why now? What kinds? In P. Murschetz (ed.) State Aid for Newspapers (pp. 49-57). Berlin: Springer.

Pickard, V. (2011). Can government support the press? Historicizing and internationalizing a policy approach to the journalism crisis. Communication Review, 14(2), 73-95.

Spieth, P., Schneckenberg, D. \& Ricart, J. (2014). Business model innovation - state of the art and future challenges for the field. R\&D Management, 44(3), 237-247.

Tang, Y., Shridhar, S., Thorson, E. \& Mantrala, M. (2011). The bricks that build the clicks: Newsroom investments and newspaper online performance. International Journal of Media Management, 13(2), 107-128.

\section{(๑) $\odot \Theta$}

Published under a Creative Commons Licence

«Attribution - NonCommercial - NoDerivs 4.0 International»

(CC BY-NC-ND) 